\title{
PENGARUH PERBEDAAN PAKAN DAN UMUR TERHADAP PERSENTASE KARKAS, MEAT BONE RATIO (MBR) DAN ORGAN-ORGAN DALAM AYAM KAMPUNG
}

\author{
Edi Suryanto *)
}

\begin{abstract}
ABSTRAK
Penelitian ini bertujuan untuk mengetahui pengaruh pakan dan umur terhadap persentase karkas, MBR dan organ-organ dalam ayam kampung.

Penelitian dilaksanakan dalam tiga tahap. tahap pertama adalah pengumpulan telur tetas, tahap kedua adalah penetasan dan tahap ketiga adalah fase pemeliharaan untuk pertumbuhan.

Telur berasal dari para pemelihara ayam kampung di daerah pedesaan Daerah Istimewa Yogyakarta dan sekitamya. Telur-telur diseleksi dan dibersihkan dengan alkohol $70 \%$ lalu dimasukkan ke dalam mesin tetas. Setelah telur-telur menetas lalu anak-anak ayam dikelompokkan dan dimasukkan ke dalam 3 petak kandang umbaran masing-masing berukuran $30 \mathrm{~m}^{2}$ dengan kandang peneduh $2 \mathrm{~m}^{2}$. Anak-anak ayam itu diberi pakan berkadar protein tinggi dengan kadar protein kasar $18 \%$ dan ME $3000 \mathrm{kcal} / \mathrm{kg}$ (PT), pakan berkadar protein rendah CP $16 \%$ dan ME $2750 \mathrm{kcal} / \mathrm{kg}$ (PR) dan pemberian pakan secara free choice (FC). Setelah anak-anak ayam mencapai umur yang ditentukan yaitu 6, 14 dan 20 minggu lalu dipotong. Data yang diteliti meliputi berat badan, berat karkas, persentase karkas, berat daging, berat tulang, Meat Bone Ratio (MBR) dan berat organ-organ dalam. Data yang diperoleh dianalisis variansi rancangan acak lengkap pola faktorial $3 \times 3$.

Hasil penelitian menunjukkan adanya perbedaan yang sangat nyata $(P<0,01)$ antara pakan $P T$ dengan pakan $P R$ dan FC terhadap berat badan dan berat karkas, sedangkan persentase karkasnya hanya berbeda nyata $(P<0,05)$. Persentase karkas tertinggi terdapat pada ayam kampung
\end{abstract}

* Staf pengajar jurusan Teknologi Hasil Ternak, Fakultas Peternakan UGM. yang diberi pakan PT yaitu 63,3\%. Dengan meningkatnya umur meningkat pula berat badan, berat karkas dan persentase karkas $(\mathrm{P}<0,01)$. MBR semakin meningkat dengan meningkatnya umur $(\mathrm{P}<0,05)$ yaitu dari $2,1: 1 ; 2,4: 1$ sampai $2,7: 1$. Perlakuan pakan tidak memberikan efek terhadap MBR. Pakan memberikan efek terhadap berat organ-organ dalam $(\mathrm{P}<0,05)$ kecuali hati dan rempelo. Umur juga berpengaruh dengan sangat nyata $(\mathrm{P}<0,01)$ terhadap pertambahan berat organ-organ dalam.

\section{PENDAHULUAN}

Ayam buras (bukan ras) yang dikenal juga sebagai ayam kampung sebenarnya mempunyai potensi cukup besar baik sebagai pensuplai daging maupun telur. Populasi ayam ini di seluruh Indonesia diantara ternak unggas yang lain menduduki tempat yang pertama yaitu sekitar 162.990.900 ekor dengan kecepatan pertambahan populasi kurang lebih 7,34\% pertahun. Namun biladibandingkan dengan ayam ras yang mempunyai populasi ayam petelur kurang lebih 38.687.800 ekor dengan kecepatan pertambahan populasi sebesar kurang lebih $45.06 \%$ per tahun sertapopulasiayam potong sebesar kurang lebih 19.195.600 ckor dan dengan kecepatan pertambahan populasi sekitar $67,68 \%$ per tahun, maka peranan ayam buras ini sudah banyak berkurang bahkan sudah digeser oleh ayam ras (Anonimus, 1988).

Ayam buras belum memperoleh perhatian yang cukup dan masih berkembang secara tradisional dengan sedikit masukan ilmu dan teknologi. Produktivitas ayam buras pun masih rendah bila dibandingkan dengan ayam ras; produksi telumya hanya $30-60$ butir per ekor tahun dan kecepatan laju pertumbuhan badan sangat lamban sehingga untuk mencapai berat badan $1 \mathrm{~kg}$ dibutuhkan waktu 6 bulan (Zainul-Bakhri, 1986). Persentase karkasnya pun hanya sekitar $61,54 \%$, sedangkan ayam ras (pedaging) 
persentase karkasnya dapat mencapai 77,39\% (SubangkitMulyono, 1982).

Karkas ayam adalah ayam yang telah disembelih, darah dikeluarkan, bulu dibuang dan dipisahkan kepala, kaki atau shank dan organ-organ dalam dada dan perut (Jull, 1951). Menurut Walters (Mountney, 1976), karkas terdiri dari sayap, kaki, paha, dada dan punggung, sedangkan karkas dengan giblet (jantung, rempelo dan hati) serta leher discbut ready to cook. Siregar (1980) menyatakan tentang bagian-bagian tubuh dari berat hidup ayam pedaging yaitu bagian karkas $65-75 \%$, darah 9 $10 \%$ leher dan kepala $17,8 \%$, kaki $4,4 \%$, bulu $6,4 \%$ dan jeroan $9-10 \%$.

Faktor-faktor yang mempengaruhi produktivitas ternak sangat komplek, tetapi pada umumnya yang paling berpengaruh adalah pakan ternak. Produktivitas ternak yang rendah di daerah tropis antara lain disebabkan, karena pakan yang diberikan pada ternak kurang memenuhi persyaratan baik kualitas maupun kuantitas. Pakan yang baik adalah pakan yang mengandung berbagai zat makanan yang dibutuhkan oleh tubuh antara lain protein, karbohidrat, lemak, mineral dan vitamin. Tinggi rendahnya kualitas ransum ayam terletak pada tinggi rendahnya kadar protein dari ransum tersebut. Kadar protein yang optimal berhubungan erat dengan derajat kecepatan tumbuh anak ayam dan bertalian dengan produksi telur (Lubis, 1963).

Pertumbuhan adalah bertambahnya jumlah sel-sel dan ini dapat diketahui dengan adanya perubahan volume dan berat dari makhluk hidupnya (Sussman, 1960). Derajat kecepatan pertumbuhan ternak khususnya anak ayam yang tertinggi dimulai sejak menetas sampai umur 1,5 bulan; mulai umur tersebut hingga umur 3 bulan kecepatan pertumbuhannya mundur kurang lebih setengahnya. Kemudian derajat pertumbuhan itu berangsur-angsur berkurang dan pada suatu saat pertumbuhan badannya berhenti sama sekali (Lubis, 1963). Suryanto (1972) menyatakan bahwa berat badan ayam kampung rata-rata sampai umur 12 minggu dengan pemberian ransum yang berkadar protein $21 \%$ dan energi (ME) $2950 \mathrm{kcal}$ adalah sebesar 751,57 gram, sedangkan hasil penelitian Widiyati (1975) menunjukkan bahwa berat badan rata-rata yang dicapai oleh anak ayam kampung pada umur 12 minggu hanya sebesar 802,05 gram untuk ayam jantan dan 690,15 gram untuk ayam betina.

Usaha-usaha untuk meningkatkan produktivitas ayam buras belum banyak dilakukan, oleh karena itu penelitian ini perlu dilakukan untuk mengetahui pengaruh pakan dan umur terhadap persentase karkas, MBR dan berar organorgan dalam ayam buras yang dipelihara secara ekstensif (umbaran).

\section{MATERI DAN METODE}

Penelitian ini dilaksanakan di Fakultas Peternakan UGM dalam 3 tahap. Tahap pertama adalah pengumpulan telur tetas, tahap kedua adalah penetasan dan tahap ketiga adalah fase pemeliharaan untuk pertumbuhan.

Telur yang digunakan dalam penelitian ini berasal dari para pemelihara ayam kampung di daerah pedesaan Daerah Istimewa Yogyakarta dan sekitarnya. Telur-telur itu kemudian diseleksi dan dibersihkan dengan alkohol $70 \%$ dan dimasukkan ke dalam mesin tetas merek "Favourites", kapasitas 750 butir. Pada saat menetas dilakukan pencatatan terhadap berat anak ayam (DOC) dan masing-masing DOC diberi nomor identitas.

Kandang yang digunakan untuk memelihara ayam yaitu kadang umbaran sejumlah 3 petak, masing-masing seluas $30 \mathrm{~m}^{2}$ dengan kandang peneduh $2 \mathrm{~m}^{2}$. Perlengkapan kandang terdiri dari alat pemanas (brooder) dengan bola lampu listrik 40 watt, tempat pakan dan minum untuk anak ayam dan ayam dewasa.

Pakan yang digunakan terdiri dari 3 jenis pakan yaitu pakan rasional berkadar protein tinggi (CP 18\% dan ME $3000 \mathrm{kca} / \mathrm{kg}$ ) atau PT, pakan rasional berkadar protein rendah (CP 16\% dan ME $2750 \mathrm{kcal} / \mathrm{kg}$ ) atau PR dan pakan secara free choice (FC). Adapun rincian bahan pakan tersebut tertera dalam tabel 1 .

Tabel 1. Bahan pakan dan susunan pakan (\%)

\begin{tabular}{lcr}
\hline Bahan pakan & Protein tinggi & Protein rendah \\
\hline Jagung & 53,0 & 18,0 \\
Bekatul & 15,5 & 61,0 \\
Bungkil kedelai & 17,0 & 6,0 \\
Bungkil kelapa & 2,0 & 4,5 \\
Tepung ikan & 8,0 & 8,0 \\
Minyak kelapa & 2,0 & 0,0 \\
Mineral & 2,5 & 2,5 \\
\hline Jumlah & 100,0 & 100,0 \\
\hline
\end{tabular}

Anak ayam (DOC) hasil penetasan dikelompokkan menjadi 3 kelompok untuk setiap jenis pakan. Kemudian setelah anak ayam mencapai umur tertentu yaitu 6,14 dan 20 minggu dilakukan pemotongan.

Parameter yang diamati meliputi persentase karkas, meat bone ratio (MBR) dan berat organ-organ dalam ayam kampung seperti jantung, hati, rempelo, ginjal dan paruparu. Data yang diperoleh kemudian dianalisis statistik pola faktorial $3 \times 3$ dan diteruskan pengujian statistiknya bila terdapat beda nyata diantara perlakuan. 


\section{HASIL DAN PEMBAHASAN}

\section{Persentase karkas}

Data persentase karkas didapat dari membagi berat karkas dengan berat badan ayam dikalikan $100 \%$. Adapun data rata-rata berat badan, berat karkas dan persentase karkas ayam kampung tertera pada tabel 2.

Hasil analisis statistik ternyata menunjukkan bahwa terdapat perbedaan yang sangat nyata untuk berat badan dan berat karkas ayam baik pada perlakuan pakan maupun umur $(\mathrm{P}<0,01)$. Dari tabel 2 terlihat bahwa berat badan

Tabel 2. Rata-rata berat badan, berat karkas dan persentase karkas ayam kampung.

\begin{tabular}{|c|c|c|c|c|}
\hline \multirow{2}{*}{$\begin{array}{l}\text { Berat badan } \\
\text { (gam) }\end{array}$} & \multicolumn{3}{|c|}{ Umur (week) } & \multirow{2}{*}{ Rata-rata } \\
\hline & 6 & 14 & 20 & \\
\hline PR & 167,1 & 632,3 & $1.218,7$ & $672,7 d$ \\
\hline PT & 201,6 & 812,3 & $1.442,7$ & $818,9 \mathrm{e}$ \\
\hline $\mathrm{FC}$ & 146,3 & 605,3 & $1,199,0$ & $650,2 d^{* *}$ \\
\hline Rata-rata & $171,7 \mathrm{a}$ & $683,3 \mathrm{~b}$ & $1.286,8$ & $* *$ \\
\hline
\end{tabular}

Berat karkas (gram)

\begin{tabular}{lllll} 
PR & 76,8 & 337,2 & 673,0 & $362,3 \mathrm{~d}$ \\
PT & 99,9 & 498,9 & 882,3 & $493,7 \mathrm{c}$ \\
FC & 63,5 & 332,9 & 661,7 & $352,7 \mathrm{~d}^{* *}$ \\
& & & \multicolumn{3}{l}{} \\
Rata-rata & $80,1 \mathrm{a}$ & $389,7 \mathrm{~b}$ & $739,0 \mathrm{c} * *$ \\
\hline
\end{tabular}

Persentase karkas (\%)

$\begin{array}{lllll}\text { PR } & 54,6 & 59,4 & 59,5 & 56,0 \mathrm{~d} \\ \text { PT } & 58,5 & 64,6 & 66,9 & 63,3 \mathrm{e} \\ \text { FC } & 54,7 & 61,7 & 60,9 & 58,9 \mathrm{~d} * \\ \text { Rata-rata } & 55,9 \mathrm{a} & 61,7 \mathrm{~b} & 62,6 \mathrm{~b} * * & \end{array}$

* berbeda nyata $(P<0,05)$

** berbeda sangat nyata $(\mathrm{P}<0,01)$

dan berat karkas ayam meningkat dengan sangat nyata seiring dengan meningkatnya umur ayam kampung $(\mathrm{P}<$ $0,01)$. Pakan dengan level protein yang tinggi memberikan berat karkas dan berat badan yang tertinggi pula $(\mathrm{P}<0,01)$. Hal ini sesuai dengan pendapat Heuser (1955) yang menyatakan bahwa pertumbuhan yang cepat pada anak ayam dapat dicapai dengan pemberian pakan yang mengandung protein tinggi. Pemberian pakan dengan cara $\mathrm{FC}$ memberikan berat badan dan berat karkas yang terendah.

Hasil penelitian Suryanto (1972) dan Widiyati (1975) menunjukkan bahwa berat badan ayam kampung umur 12 minggu berturut-turut adalah sebesar 751,57 gram dan 746,10 gram. Sedangkan hasil penelitian ini menunjukkan bahwa ayam kampung umur 14 minggu dan diberi pakan berkadar protein tinggi dapat mencapai berat $818,9 \mathrm{gram}$. Hasil penelitian ini ternyata tidak jauh berbeda.

Persentase karkas ayam kampung yang tertinggiadalah $63,3 \%$ yaitu pada pemberian pakan dengan level protein tinggi. Persentase karkas tersebut lebih tinggi dibanding dengan hasil penelitian Subangkit-Mulyono (1982) yang hanya sebesar $61,54 \%$. Tetapi bila dibandingkan dengan ayam ras pedaging (broiler), maka prestasi ayam kampung tersebut kalah jauh karena ayam broiler mempunyai persentase karkasmencapai 77,39\% (Subangkit-Mulyono, 1982). Persentase karkas ayam kampung ternyata dapat ditingkatkan besarnya yaitu melalui perbaikan pakan. Dengan meningkatnya kadar protein pakan maka akan meningkat pula persentase karkas ayam kampung ( $\mathrm{P}<$ 0,05 ).

Umur memberikan perbedaan yang sangat nyata terhadap kenaikan persentase karkas ayam kampung $(\mathrm{P}<$ 0,01 ) yaitu antara umur 14 dan 20 minggu terdapat kenaikan persentase karkas tetapi kenaikan ini secara statistik tidak berbeda nyata.

\section{Meat Bone Ratio (MBR)}

Data MBR didapat dengan cara membagi berat daging dengan berat tulang dari karkas ayam kampung. Adapun data mengenai berat daging, berat tulang dan MBR tertera pada tabel 3.

Dari tabel 3 terlihat bahwa perlakuan pakan ternyata tidak memberikan perbedaan yang nyata terhadap berat daging, berat tulang dan MBR ayam kampung. Sedangkan umur memberikan perbedaan yang sangat nyata $(P<0,01)$. Hal ini sesuai dengan pendapat Sussman (1960) yang menyatakan bahwa pertumbuhan ayam mengakibatkan bertambahnya volume dan berat ayam.

Peningkatan umur menyebabkan terjadinya kenaikan MBR secara nyata $(\mathrm{P}<0,05)$. Hal ini disebabkan karena kecepatan pertumbuhan tulang mengalami kenaikan yang pesat pada umur 4 sampai 12 minggu, sedangkan umur 12 
Tabel 3. Rata-rata berat daging, berat tulang dan MBR ayam kampung.

\begin{tabular}{|c|c|c|c|c|}
\hline \multirow{2}{*}{$\begin{array}{c}\text { Berat daging } \\
\text { (gram) }\end{array}$} & \multicolumn{3}{|c|}{ Umur (week) } & \multirow[b]{2}{*}{ Rata-rata } \\
\hline & 6 & 14 & 20 & \\
\hline $\begin{array}{l}\text { PR } \\
\text { PT } \\
\text { FC }\end{array}$ & $\begin{array}{l}49,0 \\
69,9 \\
40,8\end{array}$ & $\begin{array}{l}222,1 \\
341,4 \\
236,7\end{array}$ & $\begin{array}{l}428,0 \\
309,0 \\
428,1\end{array}$ & $\begin{array}{l}233,0 \\
238,8 \\
235,2\end{array}$ \\
\hline Rata-rata & $51,9 \mathrm{a}$ & $266,7 \mathrm{~b}$ & \multicolumn{2}{|l|}{$388,4 \mathrm{c} * *$} \\
\hline \multicolumn{5}{|c|}{ Berat tulang (gram) } \\
\hline $\mathrm{PR}$ & 21,7 & 103,5 & 161,6 & 95,6 \\
\hline $\mathrm{FT}$ & 31,0 & 147,1 & 108,1 & 95,4 \\
\hline $\mathrm{FC}$ & 21,7 & 89,5 & 168,6 & 65,7 \\
\hline Rata-rata & $24,8 \mathrm{a}$ & $113,4 \mathrm{~b}$ & $146,1 c^{*}$ & \\
\hline
\end{tabular}

MBR

$\begin{array}{lllll}\text { PR } & 2,3: 1 & 2,2: 1 & 2,6: 1 & 2,4: 1 \\ \text { PT } & 2,1: 1 & 2,3: 1 & 2,9: 1 & 2,4: 1 \\ \text { FC } & 1,9: 1 & 2,6: 1 & 2,5: 1 & 2,3: 1\end{array}$

Rata-rata $\quad 2,1: 1$ a $\quad 2,4: 1$ ab $2,7: 1 \mathrm{~b}$ *

* berbeda nyata $(\mathrm{P}<0,05)$

*** berbeda sangat nyata $(\mathrm{P}<0,01)$

sampai 20 minggu pertumbuhan tulang akan mengalami kemunduran (Jull, 1951). Uji statistik berikutnya memberikan hasil bahwa ayam kampung umur 6 dengan 14 minggu dan umur 14 dengan 20 minggu tidak berbeda nyata, tetapi MBR ayam kampung antara umur 6 dengan umur 20 minggu berbeda nyata $(\mathrm{P}<0,05)$.

\section{Organ-organ dalam ayam kampung}

Data tentang organ-organ dalam ayam kampung yang meliputi jantung, hati, rempelo, ginjal dan paru-paru tertera pada tabel 4.

Dari tabel 4 dapat dilihat bahwa berat organ-organ dalam ayam kampung yang meliputi jantung, hati, rempelo, ginjal dan paru-paru berbeda secara sangat nyata dengan meningkatnya umur $(\mathrm{P}<0,01)$, hal ini karena ayam kampung mengalami pertumbuhan dan perkembangan yaitu pertambahan besar struktur organ-organ tubuh, jaringan otot dan tulang-tulang (Jull, 1951).
Tabel 4. Berat jantung, hati, rempelo, ginjal dan paru-paru ayam kampung (gram).

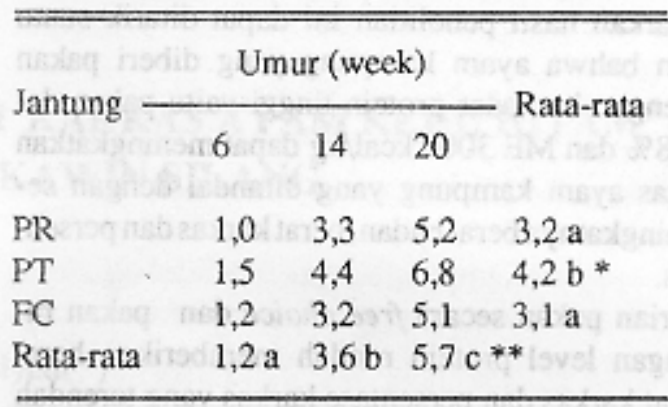

$\begin{array}{lllll}\text { Hati } & & & & \\ \text { PR } & 6,3 & 16,8 & 21,5 & 14,9 \\ \text { PT } & 6,5 & 18,2 & 34,2 & 19,7 \\ \text { FC } & 5,2 & 20,2 & 27,6 & 17,7\end{array}$

Rata-rata $\quad 6,0$ a $\quad 18,4$ b $27,8 \mathrm{c} * *$

\begin{tabular}{lllll}
\hline Rempelo & & & & \\
PR & 7,8 & 20,1 & 33,4 & 20,4 \\
PT & 9,6 & 27,1 & 36,9 & 24,5 \\
FC & 8,7 & 24,8 & 35,8 & 23,1 \\
Rata-rata & $8,7 \mathrm{a}$ & $23,9 \mathrm{~b}$ & $35,4 \mathrm{c}^{* *}$ \\
\hline Ginjal & & & & \\
PR & 2,0 & 4,2 & 7,8 & $4,7 \mathrm{a}$ \\
PT & 2,1 & 5,4 & 8,6 & $5,4 \mathrm{ab}^{*}$ \\
FC & 1,5 & 4,4 & 6,2 & $4,0 \mathrm{bc}$ \\
Rata-rata & $1,9 \mathrm{a}$ & $4,7 \mathrm{~b}$ & $7,5 \mathrm{c} * *$
\end{tabular}

Paru-paru

$\begin{array}{lllll}\text { PR } & 1,3 & 4,0 & 5,7 & 3,7 \mathrm{a}\end{array}$

$\begin{array}{lllll}\text { PT } & 2,0 & 6,4 & 11,9 & 6,8 \mathrm{~b}^{* *}\end{array}$

FC $\quad 1,2 \quad 4,0 \quad 8,2 \quad 4,5$ a

Rata-rata $\quad 1,5$ a $\quad 4,8$ b $\quad 8,6 \mathrm{c} * *$

* berbeda nyata $(\mathrm{P}<0,05)$

** berbeda sangat nyata $(\mathrm{P}<0,01)$

Perlakuan pakan memberikan pengaruh yang nyata terhadap berat organ- organ dalam ayam kampung $(\mathrm{P}<0,05)$ kecuali hati dan rempelo. Meskipun demikian ada kenaikan berat hati dan rempelo pada ayam kampung yang diberi pakan dengan level protein tinggi. 


\section{Kesimpulan}

Berdasarkan hasil penelitian ini dapat ditarik suatu kesimpulan bahwa ayam kampung yang diberi pakan rasional dengan berkadar protein tinggi yaitu pakan dengan CP $18 \%$ dan ME $3000 \mathrm{kcal} / \mathrm{kg}$ dapat meningkatkan produktifitas ayam kampung yang ditandai dengan semakin meningkatnya berat badan, berat karkas dan persentase karkas.

Pemberian pakan secara free choice dan pakan rasional dengan level protein rendah memberikan berat badan, berat karkas dan persentase karkas yang terendah sehingga pakan tersebut tidak dapat meningkatkan produktifitas ternak. Perlakuan pakan tidak meningkatkan MBR tetapi dapat meningkatkan berat organ-organ dalam ayam kampung kecuali hati dan rempelo.

Umur ternyata memberikan pengaruh yang sangat nyata pada peningkatan persentase karkas dan berat organorgan dalam ayam kampung. MBR juga meningkat dengan nyata dengan meningkatnya umur ayam kampung $(P$ $<0,05$ ).

Interaksi antara pakan dan umur tidak ada baik terhadap presentase karkas, MBR maupun organ-organ dalam ayam kampung.

\section{DAFTAR PUSTAKA}

Anonimus, 1988. Buku Statistik Peternakan. Direktorat Jenderal Peternakan, Departemen Pertanian, Jakarta.

Heuser, G.F., 1955. Feeding Poultry. Third Edition. John Wiley and Sons Inc. New York, USA.
Jull, A.M., 1951, Poultry Husbandry, Third Edition. Mc Grow Hill Book Co. Inc., Toronto, New York and London.

Lubis, D.A., 1963. Ilmu Makanan Ternak. Cetakan ke 2, PT Pembangunan, Jakarta.

Mountney, G.J., 1976. Poultry Product Technology. Second Edition, The Avi Publishing, West Point Connecticut.

Siregar, A.P., M. Sabrani dan S. Pramu, 1980. Teknik Beternak ayam pedaging di Indonesia. Margie Group, Jakarta.

Subangkit-Mulyono, 1982. Pengaruh penggunaan buah daging kopi ransum terhadap persentase karkas, persentase lemak viscera dan kadar lemak kulit ayam pedaging. Skripsi Sarjana Peternakan, Fakultas Peternakan UGM, Yogyakarta.

Suryanto, 1972. Perkembangan anak sayur dan anak ayam White Leghorn umur 1 - 12 minggu. Skripsi Sarjana Peternakan, Fakultas Peternakan UGM, Yogyakarta.

Sussman, M., 1960. Animal Growth and Development. Prentice Hall Inc., Englewood Cliffe, New Jerscy.

Widiyati, 1975. Kemungkinan timbulnya sifat heterosis dalam pertumbuhan anak ayam persilangan antara ayam kedu hitam dengan ayam kampung. Skripsi Sarjana Peternakan, Fakultas Peternakan UGM, Yogyakarta.

Zainul-Bakhri, 1986. Meningkatkan Produktifitas ayam kampung. Poultry Indonesia no. 81 September 1986. Margie Group, Jakarta. 